\title{
Value Improving Practices in Production of Hydrocarbon Resources in the Arctic Regions
}

Tatyana Semenova

Citation: Semenova, T. Value Improving Practices in Production of Hydrocarbon Resources in the Arctic Regions. J. Mar. Sci. Eng. 2022, 10, 187. https://doi.org/10.3390/ jmse10020187

Academic Editor: Claudio Ferrari

Received: 5 January 2022

Accepted: 28 January 2022

Published: 30 January 2022

Publisher's Note: MDPI stays neutral with regard to jurisdictional claims in published maps and institutional affiliations.

Copyright: (c) 2022 by the author. Licensee MDPI, Basel, Switzerland. This article is an open access article distributed under the terms and conditions of the Creative Commons Attribution (CC BY) license (https:// creativecommons.org/licenses/by/ $4.0 /)$.
Economics, Organization and Management Department, Saint Petersburg Mining University, 21 Line, 2, 199106 Saint Petersburg, Russia; tknow@mail.ru

\begin{abstract}
The relevance of the article is due to the fact that as the ice melts, the Arctic Ocean is becoming increasingly available. This fact has renewed the interest in Arctic mineral resources. The purpose of this article is to study special aspects of the development of Arctic hydrocarbon resources, which can boost the economic growth of the Russian economy in the medium term, and to identify approaches to enhance the economic value of these processes. The purpose was achieved by the solution of the following objectives: analysis of the current state of the Arctic resources, as well as the situation on both the global and Russian markets for hydrocarbon resources; study of the special part played by Arctic marine hydrocarbons; and substantiation of the development of transport infrastructure as an important factor in enhancing the economic efficiency of the production of offshore hydrocarbon resources in the Arctic Regions. The methodological framework of the article is formed by the fundamental provisions of economic theory, national economy, economic, environmental and energy security, as well as discoveries and developments by foreign and domestic scientists to ensure the economic efficiency of offshore hydrocarbon production in the Arctic Regions. The author's sequence of stages for calculating the technical and economic potential of offshore oil and gas fields in the Arctic is proposed, which, unlike the existing ones, is based on an integral indicator combining financial, technical, climatic and service-infrastructure characteristics of fields, which makes it possible to make a rating of fields to determine the order and priority of the beginning of their development. The necessity of taking into account a wide list of factors in the comparative analysis of oil and gas fields in the Arctic in order to make strategic management decisions on the priority of field development is proved. The article suggests that the organizational structure and legal support be differentiated by management levels (mega-level, macro-level, meso-level, and micro-level), as it pertains to the extraction of marine hydrocarbon resources in the Arctic Regions and the development of the transport infrastructure of the Northern Sea Route.
\end{abstract}

Keywords: offshore projects; mineral resources; climate change; transport infrastructure; oil; gas; the Northern Sea Route

\section{Introduction}

In recent years, the Arctic Regions have attracted increasing attention. Global warming is forcing the Arctic ice to retreat far and wide, making the Arctic Regions more accessible. At the same time, the growth of the world population, accompanied by increasing purchasing power, causes the growing need for energy and minerals throughout the world. Coupled with the fact that a number of existing mines and fields are being depleted with time, this means that mining and oil companies are looking for new sites to extract raw materials, thus prompting more companies and people to consider the Arctic and the vast resources that are becoming increasingly accessible due to climate change and ice retreat [1].

In general, the growth in demand for minerals is caused by three factors: (1) the growth of the world population, (2) the constantly improving world standard of living and greater purchasing power, (3) an increased share of consumer goods that contain minerals. Increased demand, coupled with the fact that the extraction of minerals is becoming more 
expensive, has for a long period of time led to higher prices in the world market (although, of course, there are short-term fluctuations, and economic crises periodically lead to a drop in prices for many mineral resources).

Due to the general rise in prices in the global market, the Arctic Regions are gaining attention as a future focus area for mining, despite the fact that they are difficult and expensive to work with, due to the harsh climate, substandard infrastructure and difficulties in obtaining energy for mining [2]. The recent drop in market prices has also slightly reduced the interest, but with expectations for higher world market prices in the future, interest is expected to renew. Growth of production of large deposits of minerals in the Arctic Regions will increase demand for maritime activities and the development of transport infrastructure [3,4].

\section{Literature Review}

The problem of the development of the Arctic territories has long been of concern to the world scientific community. Among the many studies devoted to the problems of increasing the economic efficiency of the production of offshore hydrocarbon resources in the Arctic, we highlight the following: a report by the US Geological Survey in 2021 [5], Lindholt L., Glomsrod S. in the article "The role of the Arctic in the future global petroleum supply" [6], considering the importance of the geographical distribution of geological reserves between countries, namely: the Russian Federation owns $41 \%$ of the Arctic oil resources, the USA-28\%, Greenland-18\%, Canada-9\%, Norway-4\%. Russia also dominates in natural gas production $(70 \%)$, followed by the United States (Alaska) with a share of $14 \%$. The issues of the possibility of production in the Arctic region are also considered, taking into account technological, logistical, environmental and other aspects in the report of the National Petroleum Council $[7,8]$. In addition, according to Zhao Long [9], M. Rosen [10] and other researchers [11-13], the Arctic region can also be of great importance in terms of communication as the shortest sea route between the European part of Russia and the far east, the route of the northwest Atlantic-Pacific, as well as an air route connecting North America with southeast Asia.

Many studies focus on the climatic problems associated with the development of Arctic deposits, e.g., the article by C.M. Ricksey, Oil and Sustainability in the Arctic Circle, which analyzes the problem of Arctic ecosystems under the threat of pollution by oil and gas companies and the related infrastructure [14]. In addition, the long-term demand for fossil fuels, taking into account the Paris Agreement and international objectives of climate protection, casts doubt on the feasibility of using the Arctic fuel resources [15,16]. A considerble amount of research is devoted to the ultimate geopolitical significance of the Arctic Region, since it covers the northern part of the mainland of Eurasia, North America, almost the entire Arctic Ocean, with its islands, and the adjacent parts of the Atlantic and Pacific Ocean, with a total area of 21 million square kilometers [17].

This study reveals the problem of the extraction of hydrocarbon resources in its totality, covering the possibility of the institutional and legal regulation of the development of the Arctic zone, taking into account the satisfaction of the needs of all stakeholders. We substantiate the need for the four-level interaction at the mega-level, macro-level, mesolevel and micro-level, aimed at a comprehensive response to any problem that emerges. The institutional framework for managing the development of the Northern Sea Route (hereinafter referred to as the NSR), proposed in this article to improve the efficiency of the extraction of hydrocarbon resources in the Arctic Region, can ensure the purposeful and effective development of the region and its infrastructure, which is one of the priorities of public administration in the development of international relations [18].

The purpose of this article is to study special aspects of the development of Arctic hydrocarbon resources, which can boost the economic growth of the Russian economy in the medium term, and to identify approaches to enhance the economic value of these processes. The purpose was achieved by the solution of the following objectives: (1) analysis of the current situation on both the global and Russian markets for hydrocarbon resources; (2) 
study of the special part played by Arctic marine hydrocarbons; (3) substantiation of the development of transport infrastructure as an important factor in enhancing the economic efficiency of the production of offshore hydrocarbon resources in the Arctic Regions. The scientific results of this study are the substantiation of the need to differentiate the organizational and institutional-legal structures of management for the processes of the production of marine hydrocarbon resources in the Arctic Region, on the basis of management levels (mega-level, macro-level, meso-level and micro-level). It has been substantiated that to utilize the potential of the Arctic hydrocarbon resources, the development of the transport infrastructure of the Northern Sea Route is the priority.

\section{Methodology}

The methodological framework of the article is formed by the fundamental provisions of economic theory, national economy, economic, environmental and energy security, as well as discoveries and developments by foreign and domestic scientists to ensure the economic efficiency of offshore hydrocarbon production in the Arctic Regions. Initially, special attention was paid to critical aspects such as the assessment of the current state of the world market for hydrocarbons, as well as the special part played by Arctic marine hydrocarbons [17].

As part of the work, monographs, articles in scientific publications were used, and materials from analytical centers were also analyzed. The information base of the study was scientific works on the national economy, regulatory support in the field of spatial development of the Arctic, conceptual, programmatic, information and analytical materials of state institutions on the issues under study, data from companies developing and extracting marine hydrocarbon resources in the Arctic. In the process of solving the tasks set, scientific methods of cognition were used: methods of theoretical generalization and comparison- to reveal the essence and content of the conceptual apparatus of the study of the Arctic; the method of economic and statistical analysis using the Harrington scale [18] — to study the dynamics and structure, grouping, comparing and visually displaying empirical data characterizing the development of transport infrastructure; a systematic approach-to substantiate proposals for improving the economic efficiency of the extraction of marine hydrocarbon resources in the Arctic; the method of integrated analysis according to the method of V. Plyuta [19] — to understand the effectiveness and disclosure of the technical and economic potential of deposits. Taking into account the scale and types of activities carried out in the oil and gas complex of the Arctic shelf, including investment projects for the development of fields, there are many key provisions, approaches, methods and methods for determining the potential of fields and their economic efficiency, developed and proven in the process of many years of foreign and Russian practice [19]. The existing methods for evaluating the effectiveness of oil and gas projects are mainly based on the analysis of material and financial flows, which form the basis for the formation of evaluation criteria for the effectiveness of the project. It should be noted that such approaches lie in the plane of financial analysis, without affecting such important characteristics as the technical and economic potential of the evaluated fields, as well as assessing their impact on the level of socio-economic development of nearby territories. The insufficient development of these areas, as well as the orientation of existing methods for evaluating the effectiveness of design solutions in the field of oil and gas field development, mainly towards financial analysis, led to the need to develop a comprehensive mechanism for strategic management of the development of offshore hydrocarbon fields in the Arctic, which is based on the level of development of the potential of the analyzed objects, taking into account the extended list of characteristics. Exploited hydrocarbon deposits in the Arctic, in terms of their technical and economic indicators, are at different levels of development. Having this information, decision makers form strategic directions of development in relation to the specifics of each field, including determining the order of their state support. In a broad sense, the concept is interpreted as a system of views on any object, phenomenon or process [20]. Therefore, the concept of assessing the level of development of non-gas fields in the Arctic 
should be defined as a system of theoretical and methodological approaches and tools for developing an integrated methodology that allows aggregating existing plans for the development of fields, making a quantitative mathematical calculation of the technical and economic potential of fields and determining project efficiency indicators, as well as provide information on the impact of the level of development of deposits on the socio-economic development of territories.

\section{Methodology for a Comprehensive Assessment of the Potential of Hydrocarbon Deposits}

Assessing the level of development of oil and gas fields in terms of a set of indicators, one may encounter a situation where the same object, according to different characteristics, can occupy both leading and lagging positions in the comparative ranking of fields. For example, deposits in the waters of the Pechora Sea are distinguished by relatively low indicators in terms of sea depth and distance from the coastline, but they have severe ice conditions. Thus, according to the first two characteristics, these fields can be attributed to the most favorable for development in comparison with the fields of the Barents and Kara Seas, and the characteristics of severe ice conditions indicate the opposite. A similar situation is observed in a comparative analysis of deposits in terms of other parameters. This allows us to conclude that when comparing several fields in order to select projects in order of development, it is necessary to take into account as many parameters as possible, both quantitative and qualitative, that characterize their features in many ways. A complex indicator aggregating a set of various parameters for the purposes of this study is proposed to be interpreted as the «level of development of oil and gas fields». To formalize the heuristic information, we use the Harrington scale. The Harrington scale has an analytical description in the form of a utility function:

$$
y=\exp [-\exp (-x)], 0 \leq y \leq 1,
$$

where $x$ is the value under study in the range $(-6 ; 6)$.

Using the Harrington scale, one can bring vector estimates with different dimensions to a dimensionless form. The Harrington scale [18] is a multi-interval discrete verbalnumerical scale, consisting of five intervals of a single segment, characterizing the degree of approximation to a certain ideal:

- $\quad$ very high (0.8-1.0);

- $\quad$ high (0.63-0.8);

- medium (0.37-0.63);

- $\quad \operatorname{low}(0.2-0.37)$;

- $\quad$ very low (0-0.2).

The numerical values of the Harrington scale gradations are obtained on the basis of the analysis and processing of a large array of statistical expert data. It converts qualitative assessments into quantitative ones in the range from 0 to 1 , based on the statistical processing of the psychological characteristics of a person (psychometric scale). The Harrington scale is universal and can be used to assess various quality indicators. The original psychometric scale for constructing the Harrington scale is the Likert scale. Usually, five gradations are distinguished in it, for example:

- completely disagree-do not agree;

- $\quad$ somewhere in the middle-agree;

- fully agree.

The Likert scale is ordinal, and Harrington translated it into a quantitative scale that specifies the width of the intervals (interval scale). For the technical potential of deposits $(\mathrm{T})$ :

$\mathrm{X}_{1}$-distance from the coastline, $\mathrm{km}$;

$X_{2}$ - sea depth in the field area, $m$;

$\mathrm{X}_{3}$-ice conditions; 
$\mathrm{X}_{4}$-availability of a developed coastal service infrastructure;

$\mathrm{X}_{5}$ - availability of technologies for field development;

$\mathrm{X}_{6}$ - logistical availability.

For the economic potential of deposits (E):

$\mathrm{X}_{7}$-is the forecast volume of energy resources production, billion $\mathrm{m}^{3}$;

$\mathrm{X}_{8}$-the presence of a sales market;

$\mathrm{X}_{9}$-volume of capital investments, mln USD;

$\mathrm{X}_{10}$-operating costs, mln USD;

$\mathrm{X}_{11}$-investor's income, $\mathrm{mln}$ USD;

$\mathrm{X}_{12}$-project profitability index, $\%$.

Of the totality of the presented indicators, some are quantitatively commensurate, and some have only qualitative characteristics. In this regard, it is necessary to give quantitative values to the qualitative parameters with the help of scoring.

The calculation of the integral indicator in accordance with the method of V. Plyuta [19] is proposed to be carried out in 4 stages.

Stage 1. Standardization of indicators. At this stage, the matrix is built and its elements are defined as a system of indicators of the technical and economic potential of oil and gas fields. Such indicators are heterogeneous, since they are expressed both in absolute and relative values, which makes it impossible to perform simple arithmetic operations necessary to calculate the integral indicator.

Stage 2. Differentiation of indicators. All used indicators describing the technical and economic potential of oil and gas fields are divided into stimulants and destimulators. The basis for such a classification of indicators is the nature of their influence on the level of field development. Parameters that have a positive, stimulating effect on the level of development of deposits are called stimulators. Parameters that slow down or negatively affect the level of development of deposits are called destimulators.

Stage 3. Calculation of the distance matrix. Based on the results of standardization of indicators, the distance matrix is calculated.

Stage 4. Calculation of the integral indicator. Previously obtained distances are used to calculate the final technical and economic potential of oil and gas fields, which quantifies all aggregated indicators. The integral indicator of the level of development of oil and gas fields, represented in this paper by their technical and economic potential, is positive and ranges from 0 to 1 . Detailed results of the study using these methods will be considered below.

\section{Results}

4.1. Results of a Comparative Statistical Analysis of International Companies Producing Offshore Hydrocarbons in the Arctic

Based on the indicated methods, below we note the results of the studies. The conducted comparative statistical study made it possible to show that the undoubted strength of the production of offshore hydrocarbons in the Arctic is that several companies already operate in these conditions and have unique experience in the special offshore conditions of the Arctic $[19,20]$. This, combined with the fact that Russia's merchant fleet has a strong position in the world, allows it to compete successfully in the future. Abroad, the development of marine hydrocarbon resources in the Arctic is carried out mainly in the United States (Alaska) and Norway. In the US, oil production is carried out by such major companies as ExxonMobil, BP, Shell and others. The Arctic and the Northern Sea Route are one of the main growth drivers for the oil and gas industry in the coming decades [21], and fuel and energy facilities act as a «locomotive» for the formation of regional infrastructure and accelerate the socio-economic development of the Arctic [22]. According to the National Petroleum Council, the Arctic accounts for up to $25 \%$ of all undiscovered traditional hydrocarbon resources of the planet, of which the discovered oil and gas reserves in this region amount to 191 billion barrels of oil equivalent, and potential resources are estimated at 
525 billion barrels of oil equivalent, a significant part of the hydrocarbon potential of the Arctic falls on the shelf of the Arctic seas (Table 1).

Table 1. Total potential resources of traditional hydrocarbons in the Arctic and their distribution by country, billion barrels of oil equivalent.

\begin{tabular}{lccccc}
\hline & Oil & Gas & Gas Condensate & Total & Including Offshore \\
\hline USA & 34 & 60 & 7 & 101 & 55 \\
Canada & 15 & 19 & 2 & 36 & 29 \\
Russia & 36 & 251 & 29 & 316 & 235 \\
Greenland & 16 & 23 & 9 & 48 & 46 \\
(Denmark) & 5 & 20 & & 25 & 25 \\
Norway & 106 & 373 & 47 & 525 & \\
Total & & & &
\end{tabular}

Our study demonstrates that the undoubted strength of offshore hydrocarbon production in the Arctic is that some companies already have unique experiences of working in the special Arctic marine conditions [23]. Combined with the fact that the Russian merchant fleet has a strong position in the world, this allows for successful competing in the future.

Offshore production will benefit greatly from the development of the Northern Sea Route (hereinafter, the NSR), which is necessary for hydrocarbon production in the Arctic Regions. The benefits are ice management, drifting ice monitoring and iceberg towing. It also holds promise in the delivery of oil and gas from the fields to their destinationespecially because of the technical difficulties in laying pipelines for drilling platforms in the Arctic. In addition, emergency preparedness in the event of small oil spills will be required $[24,25]$.

In the past decade, the interest has deepened in oil and gas production in the Arctic Regions. According to the Geological Survey, the Arctic accommodates 13 percent of the world's undiscovered oil reserves and up to 30 percent of the global undiscovered gas reserves (Figure 1).

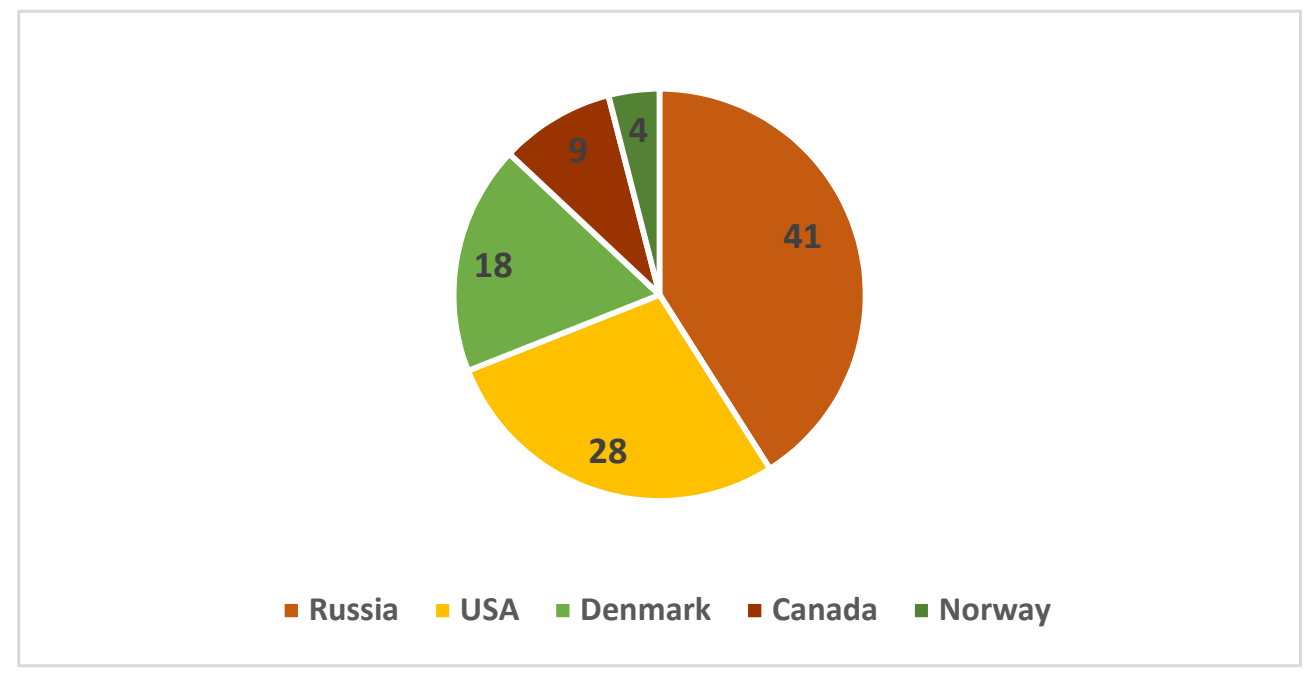

Figure 1. The structure of undiscovered Arctic oil reserves by states, \%. Data from $[25,26]$.

As we can see in Figure 2, Russia owns most of the Arctic gas and oil. Since the profitability of oil and gas production is inextricably linked to their price on the world market, higher prices are likely to be the main reason for the interest in oil and gas production in the Arctic Regions. However, in recent years, there has been a stagnation in oil and gas price behaviors (Figure 3), which is partly due to the economic crisis, and partly due to large extractable deposits of shale gas and oil. 


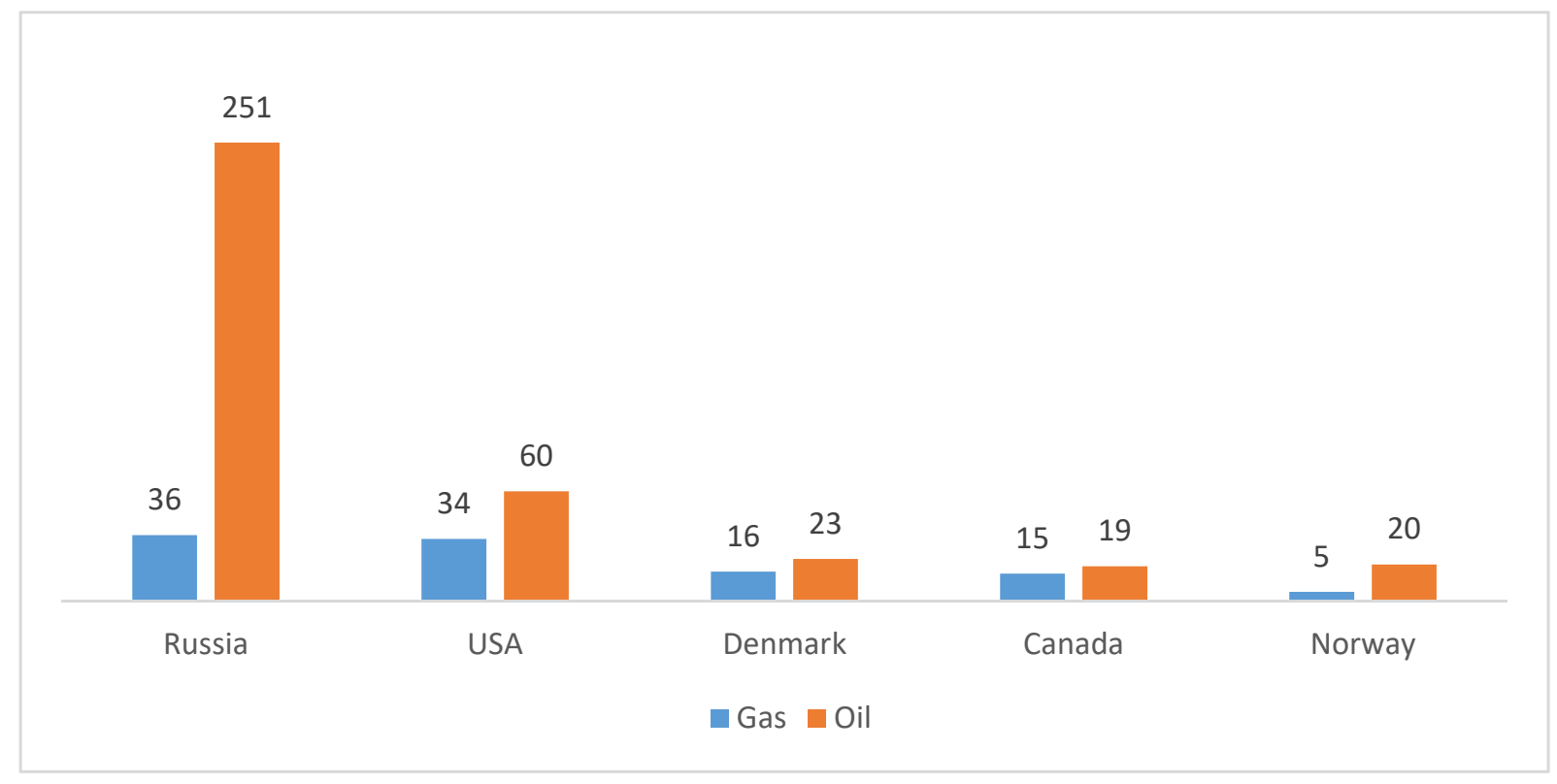

Figure 2. The conditional potential resources of the Arctic Regions (in billions of barrels of oil equivalent). Data from $[25,26]$.

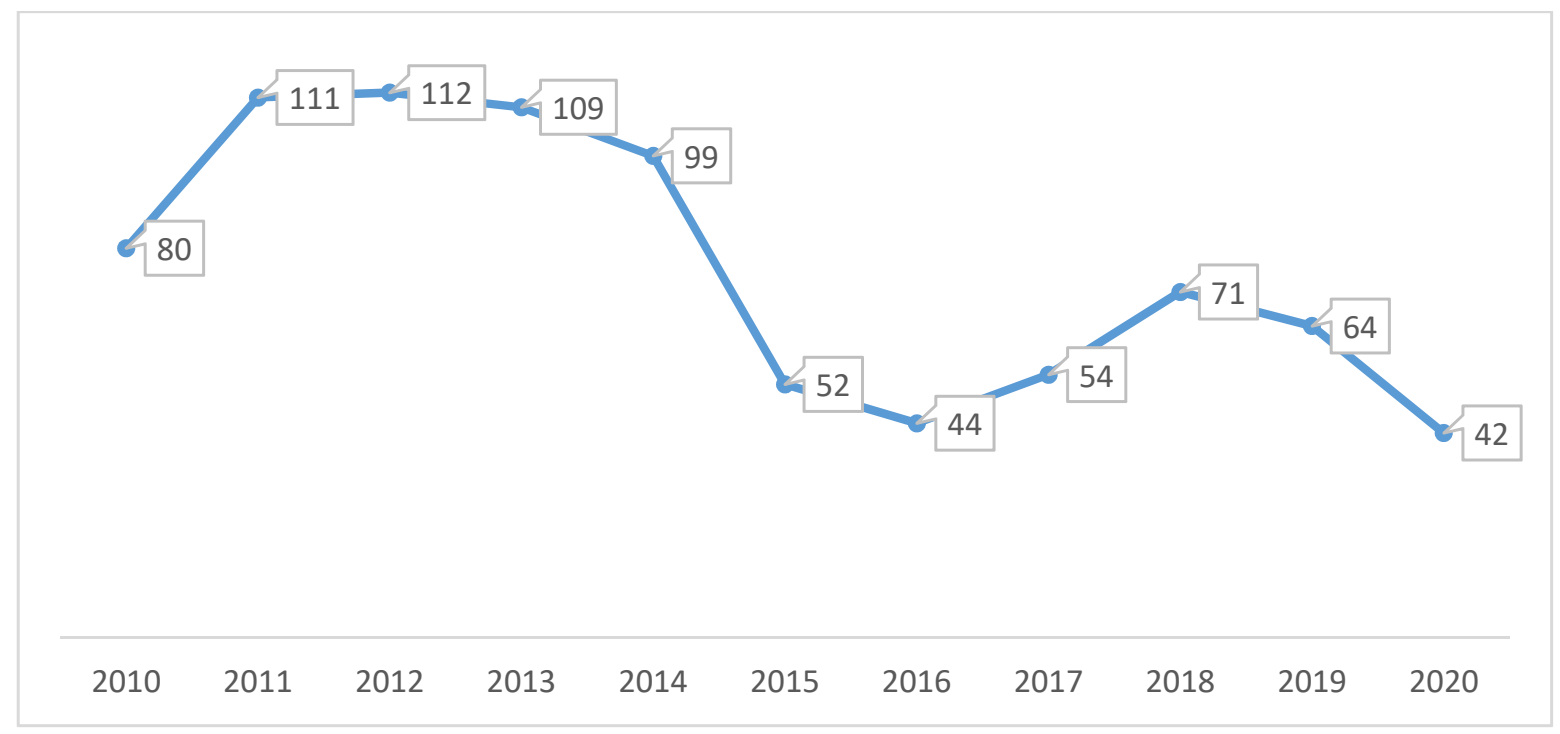

Figure 3. Brent crude oil price behavior, US dollars [25].

This probably has favored the slowdown in the progress of events in the Arctic, when, for example, Gazprom, Total and Statoil in 2010 abandoned gas production from the Shtokman gas field in the Barents Sea due to rising costs and unfavorable market conditions [27]. At the same time, there is a suggestion that the use of fossil fuels should be reduced, which may slow down the development of the region over time [28-30]. The above testify to more moderate expectations regarding the development of exploration and production of oil and gas in the Arctic in the last few years-especially in the short term and in relation to offshore fields [31-33].

Today Canada, Russia and the United States produce oil and natural gas onshore in the Arctic region, Norway, Russia and the United States, mining these two fossils offshore. Figure 4 provides information on the production of oil and gas condensate in the shelf area of the Russian Arctic. To study and make use of international experience in the interaction between the parties involved in the process of extraction is necessary [34]. 


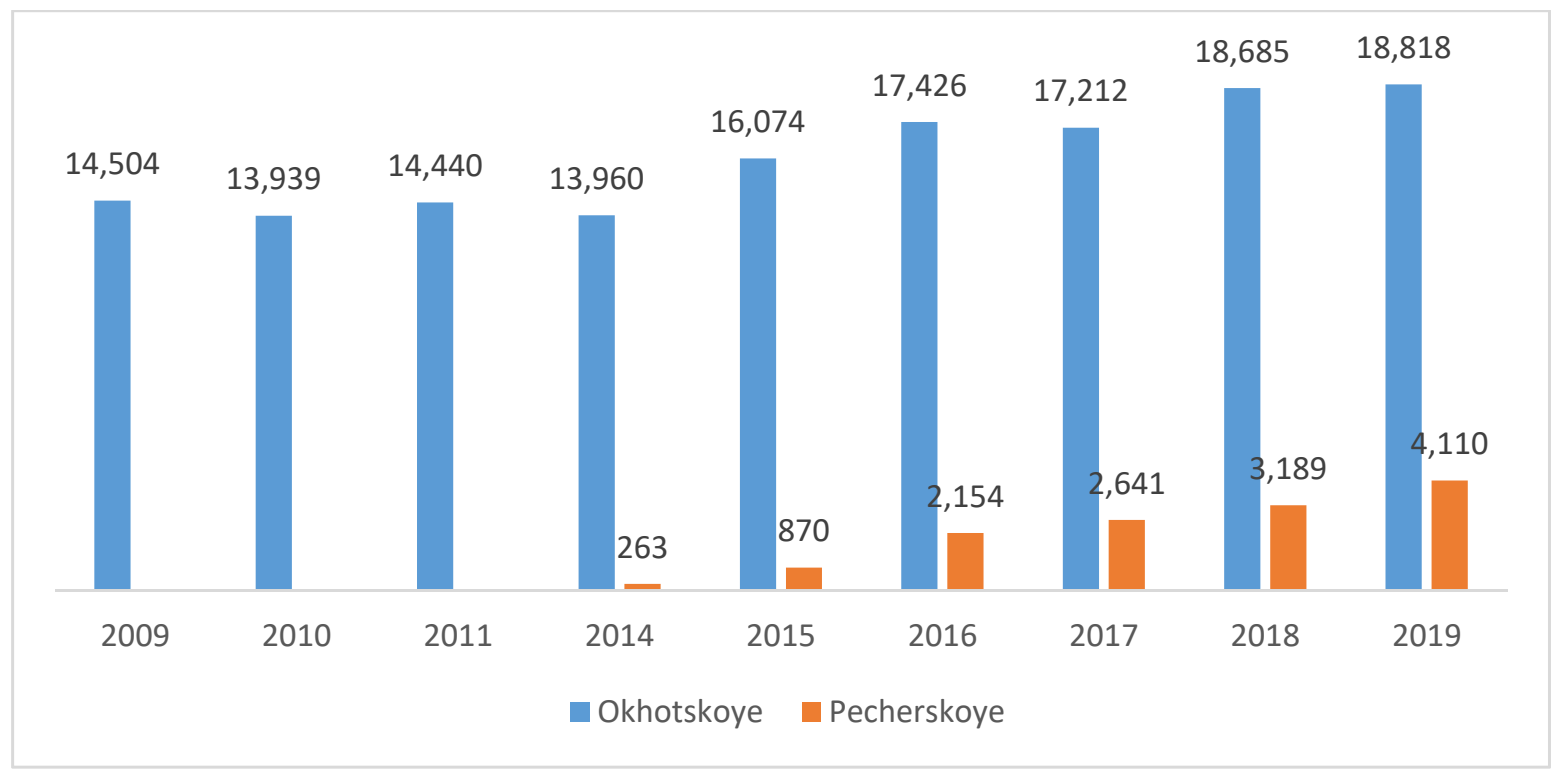

Figure 4. Production of oil and gas condensate in the shelf area of the Russian Arctic, thousand tons. Data from [35].

As we can see, hydrocarbons are mainly produced in the Sea of Okhotsk, but since 2014, the Pechora Sea has been employed, with the growth rate being even higher (Figure 5).

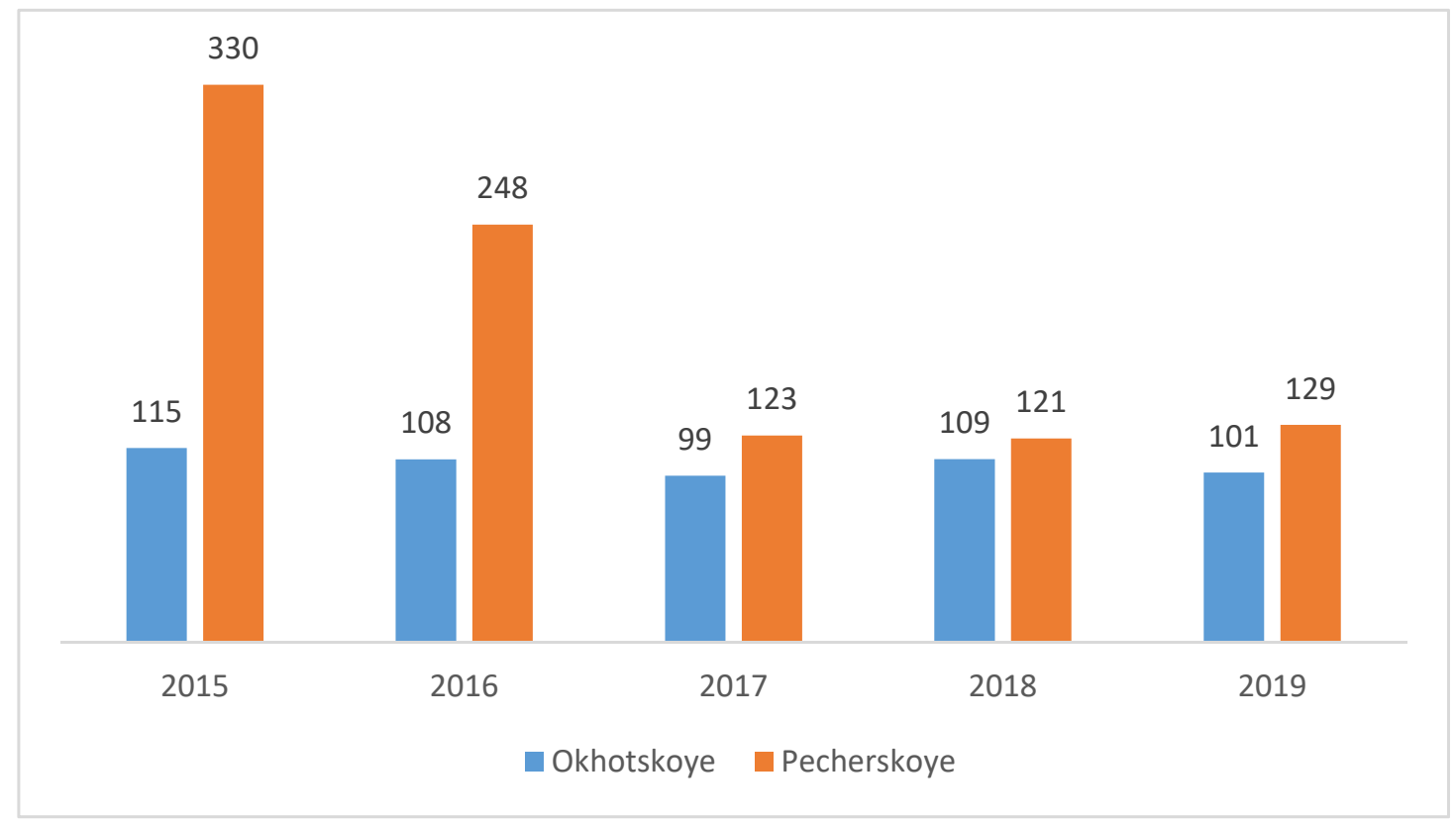

Figure 5. Growth rate of the production of oil and gas condensate in the shelf area of the Russian Arctic, \%. Data from [35].

Today, it is Russia and Norway that are interested in the development of offshore hydrocarbon resources for political and economic reasons. The Arctic Regions have been scrutinized by political and economic communities, since the climate change has led to the rapid loss of sea ice and extended economic opportunities. Russia's economy will significantly benefit from the sales proceeds of these resources [36].

However, for the marine environment and for the indigenous communities that live off the Arctic's marine resources, the development of oil in the Arctic Regions is risk bearing. A major oil spill in the region will inevitably cause economic losses, since natural yields 
will be reduced, and pristine wilderness will be lost. An analysis of the benefits and costs of developing oil in this region suggests that these risks and high production costs may not have a sufficient bottom line. This article does not directly address the costs of greenhouse gas emissions from burning these resources; however, if offshore hydrocarbon producers have to shoulder the costs of climate change equal to the social cost of carbon pollution, production costs will rise so that no offshore oil field is viable to develop [36]. It is necessary to provide technical and technological support for all works that are performed $[37,38]$. In this area, it is necessary to look more actively for ways of innovative development $[39,40]$.

4.2. Results of Econometric Analysis of Russian Fields in the Arctic Using the Harrington Scale and Integral Analysis According to the Method of V. Plyuta-To Reveal the Technical and Economic Potential of Fields

To ensure a methodologically sound translation of qualitative characteristics into quantitative indicators, it is advisable to use the Harrington scale [10]. In accordance with this technique, three evaluation gradations of the severity of parameter changes were adopted, which made it possible to present the abbreviated Harrington scale in the following form in Table 2.

Table 2. Reduced scale Harrington to determine quantitative values.

\begin{tabular}{lcc}
\hline \multicolumn{1}{c}{ Indicator } & Qualitative Assessment & Quantitative Value \\
\hline $\mathrm{X}_{3}$-ice conditions & lungs & $0.7-1.0$ \\
& medium & $0.46-0.70$ \\
heavy & $0-0.45$ \\
\hline $\mathrm{X}_{4}$ - availability of a developed coastal & exists & $0.71-1.0$ \\
service infrastructure & underdeveloped & $0.46-0.70$ \\
& missing & $0-0.45$ \\
$\mathrm{X}_{5}$-availability of technologies for field & exists & $0.71-1.0$ \\
development & underdeveloped & $0.46-0.70$ \\
& missing & $0-0.45$ \\
$\mathrm{X}_{6}-$ logistical availability & light & $0.71-1$ \\
& complex & $0.46-0.70$ \\
$\mathrm{X}_{8}-$ availability of a sales market & extreme & $0-0.45$ \\
\hline
\end{tabular}

A complete list of indicators for assessing the level of development of oil and gas fields in the Arctic based on their technical and economic potentials is presented in Table 3. 
Table 3. The input parameters to assess the level of development of oil and gas fields in the Arctic.

\begin{tabular}{|c|c|c|c|c|c|c|c|c|c|c|c|c|c|c|}
\hline \multirow{2}{*}{$\begin{array}{l}\text { Water } \\
\text { Area }\end{array}$} & \multirow[t]{2}{*}{ Name of Field } & \multirow[t]{2}{*}{ Symbol } & \multicolumn{6}{|c|}{ Technical Potential of Field (T) } & \multicolumn{6}{|c|}{ Economic Potential of Field (E) } \\
\hline & & & $X_{1}$ & $X_{2}$ & $X_{3}$ & $X_{4}$ & $X_{5}$ & $X_{6}$ & $X_{7}$ & $X_{8}$ & $X_{9}$ & $X_{10}$ & $X_{11}$ & $X_{12}$ \\
\hline \multirow{6}{*}{$\begin{array}{l}\text { Pechora } \\
\text { Sea }\end{array}$} & $\begin{array}{c}\text { Pomorskoye (GC) } \\
\text { Severo- }\end{array}$ & A1 & 25 & 10 & 0.2 & 0.5 & 0.74 & 0.5 & 364.7 & 0.23 & 6756.6 & $12,854.8$ & 9475.7 & 1.23 \\
\hline & $\begin{array}{c}\text { Gulyayevskoye } \\
\text { (OGC) }\end{array}$ & $\mathrm{A} 2$ & 20 & 65 & 0.3 & 0.6 & 0.84 & 0.47 & 284.7 & 0.11 & 5382.7 & $16,947.7$ & 3295.7 & 1.32 \\
\hline & Prirazlomnoye $(\mathrm{O})$ & $\mathrm{A} 3$ & 18 & 60 & 0.1 & 0.5 & 0.73 & 0.63 & 638.6 & 0.53 & 7395.8 & $22,846.6$ & 4635.5 & 1.01 \\
\hline & Varandey-sea $(\mathrm{O})$ & A4 & 16 & 10 & 0.4 & 0.7 & 0.82 & 0.68 & 543.7 & 0.58 & 8836.6 & $29,586.7$ & 2475.6 & 1.04 \\
\hline & $\begin{array}{l}\text { Medynskoye-sea } \\
(\mathrm{O})\end{array}$ & A5 & 17 & 30 & 0.1 & 0.5 & 0.81 & 0.5 & 463.6 & 0.53 & 6384.6 & $18,476.7$ & 3846.6 & 1.11 \\
\hline & Dolganskoye (O) & A6 & 47 & 90 & 0.48 & 0.6 & 0.7 & 0.55 & 473.6 & 0.51 & 7364.7 & $19,475.7$ & 3485.6 & 1.28 \\
\hline \multirow{5}{*}{$\begin{array}{l}\text { Barents } \\
\text { Sea }\end{array}$} & $\begin{array}{c}\text { Murmansk (G) } \\
\text { Severo- }\end{array}$ & A7 & 95 & 250 & 0.78 & 0.85 & 1 & 0.77 & 736.8 & 0.51 & $24,317.6$ & $27,421.9$ & $10,532.9$ & 1.2 \\
\hline & $\begin{array}{l}\text { Knldnskoye } \\
(\mathrm{G})\end{array}$ & A8 & 250 & 280 & 0.83 & 0.52 & 0.98 & 0.76 & 624.9 & 0.51 & $22,631.9$ & $21,864.8$ & 9654.7 & 1.11 \\
\hline & $\begin{array}{c}\text { Shtokmanovskoye } \\
\text { (GC) }\end{array}$ & A9 & 230 & 550 & 0.77 & 0.01 & 0.7 & 0.1 & 1042.8 & 0.49 & $30,396.59$ & $37,281.80$ & $15,221.34$ & 1.64 \\
\hline & Ludlovskoye (G) & A10 & 220 & 670 & 0.53 & 0.01 & 0.52 & 0.11 & 317.9 & 0.12 & $15,432.8$ & 7438.09 & 2864.7 & 1.23 \\
\hline & Ice GC & $\mathrm{AH}$ & 240 & 620 & 0.52 & 0.01 & 0.58 & 0.13 & 264.8 & 0.18 & $10,632.7$ & 7249.5 & 4276.9 & 1.06 \\
\hline \multirow{4}{*}{$\begin{array}{l}\text { Kara } \\
\text { Sea }\end{array}$} & $\begin{array}{l}\text { Rusanovskoye } \\
\text { (GC) }\end{array}$ & A12 & 75 & 340 & 0.58 & 0.01 & 0.52 & 0.52 & 1003.6 & 0.5 & $30,218.8$ & $35,964.71$ & $14,765.4$ & 1.62 \\
\hline & $\begin{array}{c}\text { Leningradskoye } \\
\text { (GC) }\end{array}$ & A13 & 120 & 320 & 0.52 & 0.02 & 0.51 & 0.51 & 997.5 & 0.49 & $30,165.6$ & $32,853.65$ & $14,279.7$ & 1.59 \\
\hline & $\begin{array}{l}\text { Severo- } \\
\text { Kamennomysskoye } \\
\text { (D) }\end{array}$ & A14 & 13 & 10 & 0.2 & 0.03 & 0.51 & 0.84 & 243.8 & 0.13 & $12,865.9$ & 9346.8 & 3965.8 & 1.12 \\
\hline & $\begin{array}{l}\text { Kamennomysskoye } \\
\text { (D) }\end{array}$ & A15 & 15 & 10 & 0.3 & 0.01 & 0.54 & 0.82 & 132.7 & 0.11 & $11,743.8$ & 8356.7 & 2875.6 & 1.02 \\
\hline
\end{tabular}

Note: OGC—oil and gas; O—oil; GC—gas condensate; G—gas.

The fields of the Western Arctic Shelf (the waters of the Pechora, Barents and Kara Seas) were selected as the most promising ones, in which more than $70 \%$ of energy resources are concentrated [41]. Further, the obtained multi-dimensional characteristics must be aggregated (collapsed) into one indicator. For these purposes, the most suitable is the method of integral analysis [42,43], which allows one to formalize the whole set of features with quantitative heterogeneity into one value (integral indicator). The advantage of this method is the possibility of comparing heterogeneous indicators by aggregating them into appropriate values that are equivalent to all the signs of the technical and economic potential of deposits.

The economic interpretation of the values of the integral indicator is presented as follows: for a separate oil and gas field in the Arctic, the higher the level of its development (technical and economic potential), the closer the value of its integral indicator is to one. The general indicator «the level of development of oil and gas fields» is calculated by the weighted average method (the average value between the integral indicators of technical and economic potential). In Table 4, as a result of calculations according to the presented formulas, the analyzed oil and gas fields of the Arctic were distributed as follows. 
Table 4. Rating of the level of development of oil and gas fields in the Arctic.

\begin{tabular}{|c|c|c|c|c|c|}
\hline \multirow[b]{2}{*}{ Name of Field } & \multirow[b]{2}{*}{ Symbol } & \multicolumn{3}{|c|}{ Calculated Values of Integral Indicators } & \multirow[b]{2}{*}{$\begin{array}{l}\text { Position in the } \\
\text { Aggregate Rating }\end{array}$} \\
\hline & & $\begin{array}{c}\text { Technical Potential of } \\
\text { Field (T) }\end{array}$ & $\begin{array}{c}\text { Economic Potential of } \\
\text { Field (E) }\end{array}$ & $\begin{array}{l}\text { The Level of } \\
\text { Development of Oil and } \\
\text { Gas Fields }\end{array}$ & \\
\hline Dolginskoye (O) & A6 & 0.25 & 0.27 & 0.67 & 1 \\
\hline Murmansk (G) & A7 & 0.83 & 0.21 & 0.64 & 2 \\
\hline Varandey-Sea $(\mathrm{O})$ & A4 & 0.90 & 0.03 & 0.61 & 3 \\
\hline Severo-Kildinskoye (G) & A8 & 0.59 & 0.25 & 0.61 & 4 \\
\hline Pomorskoye (GC) & A1 & 0.34 & 0.27 & 0.59 & 5 \\
\hline Prirazlomnoye $(\mathrm{O})$ & A3 & 0.33 & 0.17 & 0.59 & 6 \\
\hline $\begin{array}{l}\text { Severo-Gulyayevskoye } \\
\text { (OGC) }\end{array}$ & A2 & 0.45 & 0.10 & 0.59 & 7 \\
\hline Medynskoye-Sea (O) & A5 & 0.35 & 0.24 & 0.59 & 8 \\
\hline Rusanovskoye (GC) & A12 & 0.16 & 0.45 & 0.57 & 9 \\
\hline Leningradskoe (GC) & A13 & 0.10 & 0.49 & 0.57 & 10 \\
\hline Shtokmanovskoye (GC) & A9 & 0.41 & 0.34 & 0.52 & 11 \\
\hline $\begin{array}{l}\text { Severo-Kamennomysskoye } \\
\text { (G) }\end{array}$ & A14 & 0.33 & 0.30 & 0.50 & 12 \\
\hline Kamennomysskoye (G) & A15 & 0.42 & 0.22 & 0.48 & 13 \\
\hline Ledovoe (GC) & A11 & 0.24 & 0.08 & 0.43 & 14 \\
\hline Ludlovskoye (G) & A10 & 0.22 & 0.11 & 0.42 & 15 \\
\hline
\end{tabular}

The method of integral analysis made it possible to aggregate (collapse) into one indicator the whole set of heterogeneous factors for each of the analyzed deposits, to compile their rating according to the size of the total technical and economic potential. For this purpose, the final rank (ranking positions) is calculated, which should be interpreted in such a way that the first rank in the rating is considered the best [44].

The results of calculations showed that such fields as Varandey-More and the Murmansk gas field have the highest level of development of technical potential, the integral indicators of which are 0.90 and 0.83 , respectively. Thus, the leading positions for the Varandey-Sea field have been achieved due to low values of indicators-stimulators, namely the distance from the coastline and the depth of the sea in the field area, which makes the conditions for the development of this field relatively favorable. For the Murmansk field, the first positions in the rating were achieved due to light ice conditions, the presence of a developed onshore service infrastructure of technologies for the development of deposits, which are defined as indicators-stimulators, that is, those that positively affect the final level of technical potential. Rusanovskoye and Leningradskoye fields have the lowest technical potential in the comparative rating, the integral indicators of which are 0.16 and 0.10 , respectively. The closing positions in the rating of these deposits are due to the relatively high values of the depth indicator in the Kara Sea, as well as the lack of a developed coastal service infrastructure [45].

The value of the average indicator for the totality of the analyzed objects is 0.39 , of which 6 fields (Varandey-More, Murmansk, Severo-Kildinskoye, Severo-Gulyayevskoye, Kamennomysskoye, Shtokmanovskoye) have a level of technical potential above average, which is a good trend on average in the industry and positively characterizes the decision to start the development of such objects. The difference between the maximum and minimum values of integral indicators of technical potential is $88 \%$, which characterizes a high degree of difference between the analyzed deposits in terms of their technical characteristics. This is one of the bases for making managerial decisions regarding the start of field development activities in the order of determining their priority. The second basis should be considered the level of economic potential of deposits. The results of calculations showed that the highest level of the development of economic potential was in such deposits as Leningradskoye, Rusanovskoye and Shtokmanovskoye, the integral indicators of which are $0.49,0.45$ and 0.34 , respectively. Thus, the leading positions for the Leningrad, Rusanovsky and Shtokman fields have been achieved due to the highest values of the indicator of the projected volume of energy production, which rightly characterizes 
these fields as unique in terms of reserves. At the same time, the Shtokman field has the maximum projected volume of energy resources, but it ranks third among these leaders. This is due to the influence of such indicators of destimulators, such as the need for large capital investments and high operating costs associated with the development of the field, which is dictated to a greater extent by the technical characteristics of the field, namely, the distance from the shore and the depth of occurrence, as well as the increased complexity of ice conditions. The lowest level of economic potential in the compiled rating are such fields as Varandey-Sea and Ice, the integral indicators of which are 0.03 and 0.08 , respectively. The closing positions in the ratings for these fields were provided by relatively low values of the projected volumes of energy production (for the Ice field) and the minimum indicator of the expected income of the investor (for the Varandey-sea field). The value of the average indicator for the totality of the analyzed objects is 0.23 , of which 8 fields (Leningrad, Rusanovskoye, Shtokmanovskoye, Severo-Kamennomysskoye, Dolginskoye, Pomorskoye, Severo-Kildinskoye and Medynskoye-Sea) have a level of economic potential above average, which is a good trend on average in the industry and positively characterizes the decision to begin development of such objects. The difference between the maximum and minimum values of the integral indicators of economic potential is more than $90 \%$, which also indicates a high degree of difference between the analyzed deposits in terms of their economic characteristics [46].

A comparative assessment of oil and gas fields based on a set of parameters characterizing their technical and economic potential indicates that some fields that are leaders in technical potential occupy the last positions in terms of economic potential. This statement is also true in the opposite direction. These circumstances necessitated the calculation of a comprehensive final integral indicator for all technical and economic parameters at once $\left\{\mathrm{X}_{1}, \ldots, \mathrm{X}_{12}\right\}$, which in this study is defined as «the level of development of oil and gas fields». Thus, it can be seen that the three leaders in the level of development of oil and gas fields in the Arctic include such objects as the Dolginskoye, Varandey-Sea and Murmansk fields, whose integral indicators are at the level of $0.67,0.61$ and 0.64 , respectively. Despite the different conditions for the extraction of energy resources and the volume of reserves of oil and gas resources, the first places in the rating were provided by such indicators as a developed onshore service infrastructure, the availability of technologies for the development of deposits and a clear sales market [47].

Thus, for these objects, stimulant indicators proved to be crucial in calculating the final integral indicator and forming the rating. At the end of the rating are the Ludlovskoye and Ice deposits, whose integral indicators are 0.42 and 0.43 , respectively. These positions are primarily due to the difficult conditions of energy resource extraction (distance from the coast, sea depth, moderate ice conditions), extreme logistical availability and an implicit sales market. In this case, despite the significant reserves of energy resources that allow us to characterize such deposits as large, the indicators-stimulators had a negative impact on the overall rating. As noted above, the choice of the priority of facilities for the development of oil and gas fields in the Arctic should be determined not only by the volume of expected energy resources, but also by the complexity of climatic conditions, which requires the use of innovative and expensive organizational and technological solutions, which, in turn, cause an increase in the cost of production. On the other hand, harsh climatic conditions are the reason for reducing the time during which maintenance personnel can be on the platforms, which leads to staff turnover and the need to attract new employees. This has an impact on the level of employment as one of the indicators of sustainable socio-economic development in the country and regions [47].

\subsection{Tools for Determining the Priority of the Development of Deposits in the Russian Arctic}

The need to create conditions for sustainable development is one of the most important tasks of ensuring sustainable economic and social development of the Arctic territories. For this reason, the strategic management of the oil and gas complex and subsoil use in the Arctic should be interconnected with the level of socio-economic development of these 
geographical areas. In order to conduct this kind of research, it is necessary to form a set of indicators. At the initial stage of assessing the level of socio-economic development of the regions, it is necessary to identify indicators that comprehensively describe the peculiarities of the impact of the development of offshore oil and gas fields on national and regional development.

To do this, the authors propose to form a number of indicators that sufficiently fully describe such properties: $a_{1}$ - the number of jobs, thousand people; $a_{2}$-investment income of the state, million dollars; $a_{3}$-tax revenues to the state budget, million dollars; $a_{4}$-percentage of GDP (GRP), \%; $a_{5}$ - the share of total emissions of pollutants into the environment, $\% ; a_{6}$-the share of polluted wastewater on a national scale. In the above list, the impact of the activities of the oil and gas complex on socio-economic development is reflected in the following indicators: $\mathrm{a}_{1}$ - the number of employed workers for the development of a particular field, characterizes social development; $\mathrm{a}_{2}, \mathrm{a}_{3}$-state revenues, characterize the impact on economic development; $\mathrm{a}_{5}, \mathrm{a}_{6}$ - the impact on the environment during the development of offshore hydrocarbon deposits in the Arctic. Based on the integral analysis methodology described above, it is proposed to make a cumulative assessment of the impact of the oil and gas complex in the development of Arctic offshore fields on the level of socio-economic development in the regions and the country [48]. The initial data for the calculations are indicated in the Table 5.

Table 5. Initial parameters for assessing the impact of Arctic offshore hydrocarbon deposits on socio-economic development.

\begin{tabular}{|c|c|c|c|c|c|c|c|}
\hline \multirow{2}{*}{ Water Area } & \multirow{2}{*}{ Name of Field } & \multicolumn{6}{|c|}{ Indicators of the Level of Socio-Economic Development } \\
\hline & & $X_{1}$ & $X_{2}$ & $X_{3}$ & $X_{4}$ & $X_{5}$ & $x_{6}$ \\
\hline \multirow{6}{*}{ Pechora Sea } & Pomorskoye (GC) & 10.2 & 6236 & 5827 & 0.21 & 3.8 & 4.1 \\
\hline & Severo-Gulyayevskoye (OGC) & 16.4 & 5285 & 4372 & 0.32 & 3.7 & 4 \\
\hline & Prirazlomnoye $(\mathrm{O})$ & 18.4 & 6384 & 5836 & 0.48 & 2.6 & 3.2 \\
\hline & Varandey-sea $(\mathrm{O})$ & 8.9 & 6735 & 5375 & 0.04 & 0.3 & 0.4 \\
\hline & Medynskoye-sea (O) & 14.5 & 5028 & 4385 & 0.3 & 2.9 & 3.1 \\
\hline & Dolganskoye $(\mathrm{O})$ & 20.4 & 9754 & 8362 & 0.55 & 1.2 & 2.4 \\
\hline \multirow{5}{*}{ Barents Sea } & Murmansk (G) & 59.5 & 11,732 & 10,632 & 0.62 & 2.9 & 4.2 \\
\hline & Severo-Knldnskoye (G) & 32.3 & 10,634 & 8264 & 0.48 & 2.8 & 3.4 \\
\hline & Shtokmanovskoye (GC) & 57.5 & 12,133 & 9629 & 0.61 & 4.2 & 6.4 \\
\hline & Ludlovskoye (G) & 53.5 & 3784 & 3398 & 0.58 & 3.4 & 3.7 \\
\hline & Ledovoe (GC) & 51.2 & 3682 & 3298 & 0.55 & 3.2 & 3.8 \\
\hline \multirow{4}{*}{ Kara Sea } & Rusanovskoye (GC) & 41.2 & 4982 & 4495 & 0.52 & 4.1 & 5.2 \\
\hline & Leningradskoye (GC) & 43.6 & 4729 & 4194 & 0.54 & 3.9 & 4 \\
\hline & Severo-Kamennomysskoye (G) & 22.5 & 4265 & 3865 & 0.32 & 3.4 & 3.8 \\
\hline & Kamennomysskoye (G) & 28.4 & 3982 & 3394 & 0.26 & 3.2 & 3.9 \\
\hline
\end{tabular}

Using V. Pluta's methodology [19], we obtain calculated values of integral indicators of the influence of the oil and gas complex on the level of socio-economic development, given together with the indicator «the level of development of oil and gas fields» in Table 6 . 
Table 6. The values of integral indicators and the assessment of their impact on the sustainability of socio-economic development.

\begin{tabular}{lccc}
\hline & & \multicolumn{2}{c}{ Coordinates of Points } \\
\cline { 3 - 4 } \multicolumn{1}{c}{ Name of Field } & Symbol & $\begin{array}{c}\text { The Impact of the Oil and } \\
\text { Gas Complex on Sustainable } \\
\text { Development }\end{array}$ & $\begin{array}{c}\text { «The Level of Development } \\
\text { of Oil and Gas Fields» }\end{array}$ \\
\hline Pomorskoye (GC) & & 0.51 & 0.59 \\
Severo-Gulyayevskoye (OGC) & A1 & 0.52 & 0.59 \\
Prirazlomnoye (O) & A2 & 0.63 & 0.59 \\
Varandey-sea (O) & A3 & 0.60 & 0.61 \\
Medynskoye-sea (O) & A4 & 0.56 & 0.59 \\
Dolganskoye (O) & A5 & 0.76 & 0.67 \\
Murmansk (G) & A6 & 0.71 & 0.64 \\
Severo-Knldnskoye (G) & A7 & 0.70 & 0.61 \\
Shtokmanovskoye (GC) & A8 & 0.55 & 0.52 \\
Ludlovskoye (G) & A9 & 0.57 & 0.42 \\
Ledovoe (GC) & A10 & 0.57 & 0.43 \\
Rusanovkkye (GC) & A11 & 0.51 & 0.57 \\
Leningradskoye (GC) & A12 & 0.56 & 0.57 \\
Severo-Kamennomysskoye (G) & A13 & 0.53 & 0.50 \\
Kamennomysskoye (G) & A14 & 0.52 & 0.48 \\
\hline
\end{tabular}

The proposed sequence of actions for a comprehensive assessment of the potential of hydrocarbon deposits in the Russian Arctic allowed us to identify and prove a number of contradictions. In this case, we are talking about the fact that the most promising regions of the Western Arctic Shelf in terms of the estimated volumes of energy reserves, as well as geographical proximity to foreign consumers, which are leaders in the rating of economic potential, occupy far from the first positions in the comparative analysis of the «level of development of oil and gas fields» for the whole set of signs. The reason for the change of positions in the aggregate rating is the influence of the climatic characteristics of the Arctic shelf, which make the objects of deposits difficult to access and complicate the conditions for their development in technical and technological terms [48]. This leads to the need for ultra-high project development costs, as well as the need for Russian companies to attract not only additional investment capital, but also new technologies and experience of foreign companies. The arrangement of objects proposed in this paper in the aggregate rating proves the need to take into account a wide list of factors in the comparative analysis of oil and gas fields in the Arctic. Thus, the methodology for analyzing projects for the development of oil and gas fields should include not only the calculation of the economic efficiency of the project, but also an assessment of the technical, infrastructural, climatic and other characteristics of the object of study. This proves the fact that contrary to the popular opinion that the largest deposits in terms of energy resources are subject to priority development, it is necessary to involve in the analysis such parameters that allow taking into account the versatile properties of the object of study [49,50].

We believe that in the decision-making process for the extraction of hydrocarbon resources, it is necessary to take into account many factors related to the fact that the Arctic is one of the most vulnerable ecosystems in the world. Environmental movements are at war between oil and gas production at sea, tourist cruises, industrial fishing and the opening of trade routes. Individual researchers have long called for a moratorium aimed at blocking any industrial exploitation of resources for fifty years. On the other hand, the limited hydrocarbon resources in traditional areas of production leads to the need to develop new deposits. This allowed us to propose directions for further improving the economic efficiency of the extraction of marine hydrocarbon resources in the Arctic. 


\section{Discussion}

5.1. Institutional Aspects of the Development of Directions for Improving the Economic Efficiency of the Extraction of Marine Hydrocarbon Resources in the Arctic

Over a fifty-year period, the average ambient temperature in the Arctic region has increased by more than $2{ }^{\circ} \mathrm{C}\left(3^{\circ} \mathrm{F}\right)$; the corresponding loss of summer sea ice was unprecedented in human history. The warming climate has kept the northern passages and parts of the Arctic Ocean ice-free for longer periods of the year, and increased economic prospects, including shipping and hydrocarbon production, have made the Arctic an issue of profound geopolitical interest [51].

One can agree that climatic change may lead to an increased need for both international cooperation and common solutions, and a renewed and intensified contest for influence [52]. On the one hand, Russia will, in particular, be willing to secure access to appropriate technologies in order to best cope with the impacts of climatic change. On the other hand, the country will turn its mind to maximization of its economic returns when the ice retreat breaks new ground. The "conditions for the transport of goods in the Arctic seas" specified in the Plan for adaptation to climatic change primarily refer to the Northeast Passage. The Northern Sea Route has been an important topic of Russian politics for many years, with high hopes put on. Changes in the ice sheet in recent years now make some suggestions true. Thanks to the route, Russia can become a hub for international shipping and reinforce its status as an Arctic superpower, and also help local communities around ports along the route. It is necessary to look for ways to ensure the sustainability of the development of territories $[52,53]$.

The Arctic is a unique and extremely fragile environment, with the indigenous communities highly dependent on their natural environment. The chain of offshore oil exploration (seismic surveys producing strong sound waves harmful to marine mammals, increased maritime traffic and the construction of platforms and pipelines that could potentially cause leaks and tides) are likely to have an environmental impact [50-53].

In view of the above and a number of considerations, to establish the institutional framework for managing the development of the NSR seems to be important in order to enhance the efficiency of hydrocarbon extraction in the Arctic Regions. In addition, we believe that it is necessary to create a single body to govern industry-specific and transport flows in the Arctic (Figure 6) [54,55].

\begin{tabular}{|c|c|c|c|}
\hline \multicolumn{4}{|c|}{ INSTITUTIONAL FRAMEWORK FOR MANAGING THE NSR BY LEVELS OF MANAGEMENT } \\
\hline \multicolumn{4}{|c|}{ SINGLE BODY GOVERNING INDUSTRY-SPECIFIC AND TRANSPORT FLOWS } \\
\hline MEGALEVEL & MACROLEVEL & MESOLEVEL & MICROLEVEL \\
\hline $\begin{array}{l}\text { International } \\
\text { organizations and } \\
\text { integration } \\
\text { associations }\end{array}$ & $\begin{array}{c}\text { The Government } \\
\text { of Russia and the } \\
\text { Ministry of } \\
\text { Transport of } \\
\text { Russia; } \\
\text { Rosmorrechflot }\end{array}$ & $\begin{array}{c}\text { Administration of the Northern } \\
\text { Sea Route under the Federal } \\
\text { Agency for Sea and River } \\
\text { Transport }\end{array}$ & $\begin{array}{c}\text { Seaport } \\
\text { Management } \\
\text { System }\end{array}$ \\
\hline
\end{tabular}

Figure 6. Cont. 


\begin{tabular}{|c|c|c|c|}
\hline \multicolumn{4}{|c|}{ BASIC LAWS AND REGULATIONS AND REGULATORY SUPPORT OF THE NSR } \\
\hline $\begin{array}{c}\text { - SOLAS } \\
\text { (International } \\
\text { Convention for the } \\
\text { Safety of Life at Sea); } \\
\text { United Nations } \\
\text { Convention on } \\
\text { Carriage Goods by } \\
\text { Sea; } \\
\text { - UNCLOS (United } \\
\text { Nations Convention } \\
\text { on the Law of the Sea, } \\
\text { etc. }\end{array}$ & $\begin{array}{l}\text { - Transport } \\
\text { Strategy of the } \\
\text { Russian } \\
\text { Federation for the } \\
\text { period until 2030; } \\
\text { - Merchant } \\
\text { Shipping Code of } \\
\text { the Russian } \\
\text { Federation dd. } \\
\text { April 30, 1999 N } \\
\text { 81-FZ (last revised } \\
\text { on June 11, 2021) }\end{array}$ & $\begin{array}{l}\text { - Federal Law “On Seaports in the } \\
\text { Russian Federation and on } \\
\text { Making Amendments to Several } \\
\text { Laws of the Russian Federation" } \\
\text { dd. November 08. } 2007 \text { N 261-FZ; } \\
\text { - Federal Law "On Seaports in the } \\
\text { Russian Federation and on } \\
\text { Making Amendments to Several } \\
\text { Laws of the Russian Federation as } \\
\text { regards state regulation of the } \\
\text { merchant shipping in the water } \\
\text { area of the Northern Sea Route } \\
\text { dd. July 28, } 2012 \text { N 132-FZ". }\end{array}$ & $\begin{array}{l}\text { - seaport } \\
\text { regulatory } \\
\text { documents } \\
\text { (Charter, } \\
\text { internal } \\
\text { regulations, } \\
\text { orders and } \\
\text { decrees); } \\
\text { - seaport } \\
\text { anticorruption } \\
\text { program; } \\
\text { - seaport } \\
\text { development } \\
\text { strategy, etc. }\end{array}$ \\
\hline
\end{tabular}

Figure 6. Institutional framework of management of the development of the NSR to enhance the efficiency of production of hydrocarbons in the Arctic Regions.

First of all, special emphasis should be put on international laws and regulations governing the relations in maritime transport infrastructure, since the legislation of a country does not necessarily cover these relations in terms of administrative and legal regulation. This is due to the fact that maritime transportation is primarily external to the state, and therefore is subject to general regulation with other stakeholders, that is, in compliance with established international norms, conditions and standards, which, in turn, are defined in the previous structures adopted by international laws and regulations.

Regulation of relations in the maritime transport infrastructure of the NSR should be purposeful and effective, which is one of the priorities of state administration in the development of international relations in the maritime transport infrastructure. In Russia, there is a priority of international law, that is, if the provisions of international treaties do not comply with the norms enshrined in the laws of Russia, then the provisions of international treaties will prevail. So, it is the state that plays the leading role in the functioning of the maritime transport infrastructure, which adopts the majority of applicable laws and regulations.

Macro-level. For the most part, the legislative documents regulating the field of transport infrastructure and the NSR determine general provisions, in particular, the regulation of the maritime transport infrastructure of Russia. A fairly large number of Russian laws and regulations regulate and influence the management of the maritime transport infrastructure of the NSR. For the NSR to function efficiently, it is necessary that all the applicable laws and regulations be consistent and complement each other in the respective areas, which will contribute to improving the quality of transport services, effective implementation of administrative reform, transparency in decision making, clear delineation of functions and distribution of powers between executive authorities and business entities, as well as ensuring the creation of a level playing field for the provision of transport services.

Meso-level. The meso- (sectorial) level is the next level of management of the maritime transport infrastructure; therefore, we will consider the main laws and regulations on the management of the maritime transport infrastructure of the NSR. The main legislative documents governing the activities of the NSR are the Federal Law "On Seaports in the Russian Federation and on Making Amendments to Certain Legislative Acts of the Russian 
Federation" dd. 08 November 2007 N 261-FZ and the Federal Law "On Making Amendments to Certain Legislative Acts of the Russian Federation as regards State Regulation of Merchant Shipping in the Water Area of the Northern Sea Route" dd. 28 July 2012 N 132-FZ, which govern relations in port activities and, in particular, establish the basic principles of state regulation of activities in seaports, the procedure for the construction, opening, expansion and closure of seaports, as well as the implementation of economic activities on their territory, including the provision of services, and determines the legal regime of port infrastructure facilities.

Among the key principles of the implementation of the state maritime policy in respect of the NSR, the following considerations should be highlighted: the priority of politicaldiplomatic, economic, informational and non-military forms of countering sea threats; reactivation of the country's naval potential; creating conditions for efficient port activities; safety of navigation; protection of human life at sea; sufficient naval potential; protection of the property rights of the Russian people to the natural resources of the continental shelf and the exclusive (maritime) economic zone of Russia.

This strategy outlines the main advantages and weak points of the functioning and development of seaports, forecasts of cargo flows, objectives, main focus areas (priorities) and ways of development of seaports and the port industry as a whole. The main objectives of the modernization of the NSR are: increasing the competitiveness of the port industry; upgrading the NSR facilities and port infrastructure; ensuring effective government regulation of specialized services provided in a merchant seaport; creation of competitive conditions for the implementation of economic activities and the receiving of services in seaports; ensuring the technological development of the port-related industry and training highly skilled professionals; raising funds for the development of maritime transport infrastructure; active involvement in international associations in order to create conditions for cross-border transportation; bringing the performances of the Russian seaports in line with European ones, etc.

Micro-level. Having reviewed the institutional framework for the management of Russia's maritime transport infrastructure at the mega-, macro- and meso-levels, let's move on to the micro-level, that is, the seaport as it is. The micro-level organization is regulated by the following documents: port regulations, a port anti-corruption program, a port development strategy, etc. Additionally, organizational regulation documents at this level can include specific contracts for the carriage of goods by sea, to be accepted by carriers or their associations. On the basis of the studies of laws and the regulatory framework of maritime transport infrastructure, it can be noted that the adaptation of the Russian laws to the legislation of the NSR-partner countries is a priority area of cooperation in the maritime transport infrastructure and is a prerequisite for integration.

We believe that the development of a strategy (either a national, regional, or local one) should be preceded by a sound and reasonable forecast of economic and social development (of a state, industry, or city). The development of programs for the economic and social development of the NSR defining the goals and priorities, and the means and ways of achievement, the formation of a mutually agreed and comprehensive system of measures of the legislative and executive authorities should be aimed at effectively solving economic and social problems and achieving stable economic growth. The unity and systemic nature of forecast, program, and strategic documents for the development of the economy of the state, region and industry is needed, as well as the consistency of the regulatory and legal framework.

The development of the NSR to enhance the economic value of the offshore hydrocarbon production provides for the achievement of the following goals:

- $\quad$ emerging role of transport, and supporting mobility while reducing emissions;

- $\quad$ an efficient platform for multimodal carriage and transport;

- a worldwide level playing field for long-distance transport and intercontinental freight traffic. 
This, in turn, entails a revision of the specific goals of the extractive industry and further development of the transport system of the NSR, which, in our opinion, should be as follows.

1. Shaping and support of a single transport space of the country based on the balanced development of transport infrastructure for the needs of the industry and the population.

2. Integration into the world and Eurasian transport system and the implementation of transit potential.

3. Provision of affordable, high-quality, national transport services competitive in foreign markets.

4. Ensuring investment attractiveness and the inflow of direct investments into the Arctic transport system.

Prior to the study, we have assumed that enhancing the economic efficiency of Arctic marine hydrocarbon resources might contribute to the Russia's economic growth, but the lag in the technologies reduces efficiency and increases costs.

5.2. The Main Directions of Development of the Directions of Increasing the Economic Efficiency of the Extraction of Marine Hydrocarbon Resources in the Arctic

The results showed that to increase the efficiency of resource extraction, the integrated development of the Arctic Regions is crucial, with the transport factor being of primary importance. Currently, the socio-industrial infrastructure of this territory is poorly developed [34]. Below are the main approaches to enhance the economic efficiency of the production of offshore hydrocarbons in the Arctic Regions, taking into account the spatial organization of the Arctic sea communications in the historical, economic and geopolitical retrospective.

1. Within the framework of the strategy for the production of offshore hydrocarbons, the economic value of these processes should be understood as the way in which the main energy facilities of the spatial structure of the Arctic are located, and the relations between them. The main units of the spatial structure of the Arctic Regions to be the subject of analysis and the impact of state policy include elements of the economic and social system, technical infrastructure, transport infrastructure networks, as well as functional connections. The concept defines the way to achieve this perspective of the desired state of spatial development of the Arctic Regions, which allows the implementation of the strategic goals of offshore hydrocarbon production to the fullest extent possible.

2. The policy of spatial development of the Arctic Regions. The country's spatial development policy indicates the way in which the perspective of spatial development and development goals in relation to the territory is implemented, influencing the main energy localities and ensuring the coordination of industry-specific tools. As an integral part of the development policy, spatial strategy reconciles and coordinates national efforts with actions taken at other levels, including regional and local government. A spatial development policy is a tool for the implementation of a long-term national development strategy and is implemented on the basis of a national spatial development strategy, horizontal development strategies, and planning documents related to: regional level (the strategy for the development of the Arctic Regions and the associated spatial development plan), functional level (the strategy and related development plans for functional areas, e.g., transport, energy, etc.), investment activities arising from development programs and operational programs, legal regulations, competent institutional solutions, including an integrated system for monitoring information on the intentions of national and regional authorities in relation to the production of offshore hydrocarbons in the Arctic Regions.

The implementation of the policy of spatial development of the Arctic Regions provides: 
- coordination of the spatial activities of state entities, which consists of combining various plans to achieve the set goals in a timely manner,

- $\quad$ creation of a platform of mutual understanding between various actors in the field of achieving goals and activities in individual sectors and areas, using the potential of the country, its individual regions and functional areas.

The actor that develops the policy for the spatial development of the Arctic regions is the government (with an appropriate structure for consultation and partnership in the programming process), while it is implemented jointly by all state structures within their competence.

The spatial development policy of the Arctic Regions is implemented using various tools. One of the most important ones is spatial planning, in which provisions are applied to spatial development at the national, regional and local levels, or to spatially separated specific territorial complexes (functional zones), based on the legal regulations. Other spatial development policy tools include legal instruments, institutions and organizational solutions other than spatial development plans that determine the effectiveness and efficiency of both the spatial planning system and related development institutions (planning and implementation). Investment activity also should be considered, especially for public purposes, planned as part of medium- and short-term strategies and programs, and this is the area of other government policies.

3. Spatial planning. As a tool for managing the development of the Arctic Regions, spatial planning is designed to formulate the goals and objectives of the policy of spatial development of the Arctic Regions and determine the way of its implementation. The main task of spatial planning is to indicate the optimal ways of use of the spatially different features of the territory to achieve development goals, to determine the spatial distribution and timing of the development of marine hydrocarbons, taking into account the synergistic effect of these efforts and preserve those features of the territory that require protection and guarantee foundations of sustainable development.

In order to improve the efficiency of offshore hydrocarbon production, the following distinction should be made in the planning system:

national planning - the authority to prepare planning documents is vested in: the

3.1 Ministry of Regional Development of the Russian Federation (the concept of the country's spatial development), the Ministry of Construction and Housing and Utilities of the Russian Federation (the Ministry of Construction of Russia) (an amendment to the law on spatial planning and development is proposed, a national spatial plan development, i.e., the national plan)—other competent ministries responsible for actions in functionally defined elements of the development of the Arctic Regions and the competence in the preparation of relevant planning documents,

functional planning - as a separate cross-cutting category of planning due to the need

3.2 to provide planning in areas with specific characteristics not related to administrative constraints, regardless of the existence of a national strategy, regional and local plans (plans of functional zones),

regional planning - the preparation of regional planning documents (such as plans for

3.3 the spatial development of regions, municipalities) is entrusted to regional competent authorities, defining the course of changes in the spatial structure and the purpose of territories; the competence is with the respective local government authorities.

Legal tools are all tools other than local-level plans for spatial development, including legislative acts related to environmental management, most of which are important for spatial management, as well strategies, programs and plans that affect the state of spatial development of the Arctic Regions. They form the basis of the planning procedure, as they support the proper implementation of the objectives of spatial policy and are used to carry out sustainable activities in the field of spatial development. The prerequisite for the proper functioning of legal tools in the planning system is their coordination with the spatial 
development policy. Spatial planning is complemented by the system of environmental impact assessments, applicable to all planning documents.

In the context of the impact of offshore hydrocarbon production on resource preservation and environmental protection, as well as on quality of life, legal regulations are needed to designate ecological networks, protected areas, emission reduction, urban climate control, etc., as well as tools for assessing the environmental stress.

4. Institutional instruments. The institutional system supports and in fact determines the proper implementation of plans to improve the efficiency of Arctic offshore hydrocarbon production. The main elements of this system are:

- a system coordinating the implementation of the policy for the production of the Arctic offshore hydrocarbons, covering all government agencies involved in the planning and implementation of the policy; coordination within the national spatial development policy includes coordination at the national, regional, local levels, as in functional areas. The multi-level institutional system for the offshore hydrocarbon production in the Arctic Regions is currently scattered and is not in a position to fulfill adequately the main tasks in the field of effective implementation of the assumptions of the spatial development policy,

- systems for monitoring the production of offshore hydrocarbons in the Arctic and the implementation of spatial policy by providing information critical for making managerial decisions at all levels of the spatial policy framework,

- personnel able to plan and control development,

- multilevel partnerships in the implementation of tasks,

- spatial and environmental data policy,

- tools to support the system in the form of ecophysiographic studies and an environmental impact assessment system, as well as systems to ensure quality management.

5. Investment tools. The proper target orientation of investment activities can contribute to the achievement of the goals of the production of offshore hydrocarbons in the Arctic. Until now, the provisions of strategic documents in the field of spatial development have not been directly linked with the provisions of socio-economic medium-term strategies and operational documents that form the basis for spending public funds on the implementation of plans for the development of Arctic resources. Taking into account the postulated emphasis on coordinating spatially oriented (or having a clear spatial impact) activities within a single integrated development policy, and due to the size of the pool of funds allocated for the implementation of projects, a significant part of the expected expenditures within the framework of public policy, as well as funds spent by local governments through various "industry-specific" allocation mechanisms, should be considered as tools of implementation of the perspective for enhancing the efficiency of offshore hydrocarbon production.

Supervision of programs and individual investment tools is usually entrusted to various management entities. It is imperative that the system for the control and coordination of offshore hydrocarbon production ensures cooperation between the subjects of interaction and makes it possible to make use of the effects of territorial tools used in programs.

\section{Conclusions}

The scientific result of the conducted research is the justification of the need to differentiate the organizational and institutional-legal structure of the management of the processes of extraction of marine hydrocarbon resources in the Arctic by management levels (mega-level, macro-level, meso-level and micro-level). It is proved that the main direction of realizing the potential of Arctic hydrocarbon resources is the development of the transport infrastructure of the Northern Sea Route. 
According to the current geological assessment, the Arctic shelf of Russia has a huge oil and gas potential: in the forecast part for oil -5.2 billion tons of recoverable resources, for gas-49.2 trillion, $\mathrm{m} 3$.

The oil resources of the Arctic waters of Russia that are technically available for development, with the current state of technology and technologies of offshore operations, amounting to about 3 billion in oil, tons, or $55 \%$ of the volume of the forecasted part of the resource potential, for gas this value reaches 27 trillion, $\mathrm{m} 3$, or $54 \%$ of the volume of forecast resources.

To date, only one oil field is under development-Prirazlomnoye-with reserves of 78.2 million tons. Another of the largest oil fields-Dolginskoye-with proven reserves of 235.8 million tons, may be involved in industrial turnover in the medium term. Due to a number of technological and economic reasons, the huge proven reserves of gas fields on the Arctic shelf are not yet in demand, with the exception of the coastal-marine Yurkharovsky oil and gas condensate field, the development of which is carried out from the shore.

The profitability of their development depends on a number of factors, among which, along with the oil, and geological and commercial characteristics, are the physical and geographical features of promising water areas associated with the depths of the sea and the ice situation within the shelf zones. Due to the complex combination of a complex of factors in the Arctic waters, only large deposits with a resource value of at least 30-100 million tons of oil and 30-100 and even 100-500 billion are considered profitable, m3 of gas.

The volume of profitable resources on the Arctic shelf reaches about 1 billion tons of oil and 22 trillion $\mathrm{m} 3$ of gas. Thus, about $18 \%$ of the total volume of projected oil resources can actually be involved in the industrial turnover in modern technical and economic conditions, and up to $44 \%$ of gas. The resource potential of technically inaccessible zones is considered as currently of no industrial significance, since there are no real technologies for its development.

The above economic assessment showed that Russia has a huge potential of hydrocarbon raw materials on the Arctic shelf, primarily gas. However, large-scale involvement of this wealth in industrial turnover will be advisable only if the situation on the world energy markets is favorable, providing an acceptable rate of return on the huge investments that are necessary for the creation of infrastructure and industrial development of offshore oil and gas fields.

It is advisable to use the results of the economic assessment of the marine hydrocarbon raw material base of the Arctic shelf when justifying regional exploration programs, including 2D regional seismic surveys and deep (parametric) drilling. Their implementation will significantly clarify and deepen the existing ideas about the oil and gas potential of the water areas, which will contribute to the formation of more realistic programs for the development of offshore resources, and build economically sound tactics and strategy for the development of the fuel and energy sector, according to the most important and critical parameters for the industry.

In the long term, Russia's approach is likely to be largely driven by the economic development of the country in general and the Russian Arctic in particular. Economic challenges seem to immediately lead to increased cooperation; however, they can provoke conflict in the long term, not least if the vast resources of the Arctic Ocean are deployed. The Arctic Regions are expected to influence significantly on the maritime industry in the prospect. This is due to the potential that is slowly being unlocked, in part due to rising prices of the raw materials and increasing accessibility of the Arctic ocean due to global warming. The potential is closely linked with the development of the mining industry, offshore oil and gas activities and the opening of Arctic passages.

Progress in the implementation of key projects of Arctic resource development, funded under sectorial and regional development programs, will depend on ongoing monitoring of the above spatial policies. The determinants of the national spatial development policy are created by a set of factors and processes that, to a small extent, depend on the actions 
of the government and other state structures. However, they should be considered when wording and implementing the policy for the spatial development of the Arctic Regions, since they can have a significant impact on the way of implementation, setting goals and their achievability. Conditions are the result of historical factors, political, demographic and economic developments, the state of the environment, and changes in technologies employed. They are also resulted from socio-economic and environmental changesboth current and prospective ones. Essential prerequisites are created by the legal and institutional situation in the Arctic Regions.

Another important consideration that determines the policy of the spatial development of the Arctic Regions is the viability of the national legal and institutional system for managing the process of development, including spatial planning. This will affect the trends in the development of international transport routes and the areas of activating the processes of functional integration of the Arctic Regions.

The consequences of decisions in determining the best spatial development are as follows: setting the goals to be achieved $\Rightarrow$ identifying possible solutions $\Rightarrow$ choosing the solutions that will achieve the goals. The spatial structure will improve through the spatial shifts of activity, making the systems optimal. Optimization is due to-taking actions in the field which will improve the state of systems, - changing the spatial division between different activities (changes in the structure of use, changes in regionalization),-increasing the scale and intensity of activities in the field which will improve the state of systems,-a change in the spatial system of connections and internal regional and interregional (as well as local) interactions, - an interregional redistribution of resources (development factors). These optimization shifts can be viewed in terms of the decision-making process. The proposed approach will enhance the production of offshore hydrocarbons in the Arctic territories for the rational development of offshore hydrocarbons.

Funding: The research was carried out at the expense of a subsidy for the implementation of the state task in the field of scientific activity for 2021 No. FSRW-2020-0014.

Institutional Review Board Statement: Not applicable.

Informed Consent Statement: Not applicable.

Data Availability Statement: Not applicable.

Conflicts of Interest: The author declare no conflict of interest.

\section{References}

1. Vakhova, E.S.; Kuropatkin, E.V. Prospects and Experience of Funding the Development of Arctic Oil and Gas Fields. Lib. Socio-Econ. Soc. Sci. 2020, 8, 118-121.

2. Brodt, L.E.K. Best Practices of Oil and Gas Companies to Develop Gas Fields on the Arctic Shelf. AiS 2021, 11, 30-44. [CrossRef]

3. Cherepovitsyn, A.E. Socio-economic potential of large-scale projects to develop offshore oil and gas: Risks and stakeholder expectations. J. Min. Inst. 2015, 215, 140-149.

4. Pusenkova, N.N. Oil on Russia's Arctic Continental Shelf: Optimism, Pessimism, Realism. Outline of Global Transformations: Politics, Economics, Law. 2019; No.5, p. 86-108. Available online: https://www.ogt-journal.com/jour/article/view/528?locale= en_US (accessed on 4 January 2022).

5. The US Geological Survey (USGS). Science for a Changing World. Available online: https://www.usgs.gov/ (accessed on 4 January 2022).

6. Lindholt, L.; Glomsrod, S. The Role of the Arctic in Future Global Petroleum Supply. Available online: https://www.ssb.no/a/ publikasjoner/pdf/DP/dp645.pdf (accessed on 4 January 2022).

7. National Petroleum Council Arctic Potential Realizing the Promise of U.S. Arctic Oil and Gas Resources. Available online: https:/ / www.npc.org/2019-Arctic_SA-LoRes.pdf (accessed on 4 January 2022).

8. Larsen, J.N.; Huskey, L. The Arctic Economy in a Global Context. In The New Arctic; Evengård, B., Larsen, J.N., Øyvind, P., Eds.; Springer International Publishing: Cham, Switzerland, 2015; pp. 159-174. [CrossRef]

9. Long, Z. On the Governance path of Russia to the Northern Sea Route and assessment of its future development. World Reg. Stud. 2016, 25, 6-10.

10. Rosen, M. Will China Freeze America Out of the Arctic? 2019. Available online: https://nationalinterest.org/feature/will-chinafreeze-america-out-arctic-73511 (accessed on 4 January 2022). 
11. Köhler, J.; Geels, F.; Kern, F.; Markard, J.; Onsongo, E.; Wieczorek, A.; Alkemade, F.; Avelino, F.; Bergek, A.; Boons, F.; et al. Agenda for Sustainability Transitions Research: State of the Art and Future Directions. Environ. Innov. Soc. Transit. 2019, 31, 1-32. [CrossRef]

12. Gorman, M.R.; Dzombak, D.A. A review of sustainable mining and resource management: Transitioning from the life cycle of the mine to the life cycle of the mineral. Resour. Conserv. Recycl. 2018, 137, 281-291. [CrossRef]

13. United States Geological Survey (USGS). Assessment of Undiscovered Oil and Gas Resources in the Cretaceous Nanushuk and Torok Formations, Alaska North Slope, and Summary of Resource Potential of the National Petroleum Reserve in Alaska. 2017. Available online: https:/ / pubs.usgs.gov/fs/2017/3088/fs20173088.pdf (accessed on 4 January 2022).

14. Rixey, C.M. Oil and sustainability in the Arctic Circle. Denver J. Int. Law Policy 2016, 44, 441-452.

15. Status of Offshore Oil and Gas Activities and Regulatory Frameworks in the Arctic. 2021. Available online: https: / / www.pame.is/document-library/pame-reports-new/pame-ministerial-deliverables/2021-12th-arctic-council-ministerialmeeting-reykjavik-iceland/797-status-report-on-offshore-oil-and-gas-activities-and-regulatory-frameworks-in-the-arctic/file (accessed on 4 January 2022).

16. Melia, N.; Haines, K.; Hawkins, E. Future of the Sea: Implications from Opening Arctic Sea Routes. 2019. Available online: https:/ / assets.publishing.service.gov.uk/government/uploads/system/uploads/attachment_data/file/634437/Future_ of_the_sea_-_implications_from_opening_arctic_sea_routes_final.pdf (accessed on 4 January 2022).

17. Snider, D. Crystal Serenity-A New Chapter in Arctic Shipping or Just 'Doing It Right'? The Arctic Yearbook. 2016. Available online: https:/ / arcticyearbook.com/arctic-yearbook/2016/2016-commentaries/194-crystal-serenity-a-new-chapter-in-arcticshipping-or-just-doing-it-right (accessed on 4 January 2022).

18. Dubina, I.N. Fundamentals of mathematical modeling of socio-economic processes. In Textbook and Workshop for Universities; Dubina, I.N., Ed.; Yurayt Publishing House: Moscow, Russia, 2022; 349p.

19. Pluta, V. Comparative multidimensional analysis in econometric modeling. In Finance and Statistics; Veslav Pluta, M., Ed.; 1989; 174p. Available online: https:/ /link.springer.com/book/10.1007/978-1-4419-6876-0 (accessed on 4 January 2022).

20. Overland, I.; Bambulyak, A.; Bourmistrov, A.; Gudmestad, O.; Mellemvik; Zolotukhin, A. Barents Sea oil and gas 2025-Three scenarios. In International Arctic Petroleum Cooperation: Barents Sea Scenarios; Routledge: Abingdon, UK, 2015; pp. 11-31.

21. Harsem, O.; Heen, K.; Rodrigues, J.M.P.; Vassdal, T. Oil exploration and sea ice projections in the Arctic. Polar Rec. 2015, 51, 91-106. [CrossRef]

22. Stouwe, E.V. An Arctic peril: The pitfalls and potential of a fragmentary polar law. Brook. J. Int. Law 2017, 43, 191-232.

23. Petrick, S.; Riemann-Campe, K.; Hoog, S.; Growitsch, C.; Schwind, H.; Gerdes, R.; Rehdanz, K. Climate change, future Arctic Sea ice, and the competitiveness of European Arctic offshore oil and gas production on world markets. Ambio 2017, 46, 410-422. [CrossRef]

24. Litvinenko, V. Foreword: Sixty-year Russian history of Antarctic sub-glacial lake exploration and Arctic natural resource development. Chem. Erde 2020, 80, 125652. [CrossRef]

25. Johannsdottir, L.; Cook, D. Systemic risk of maritime-related oil spills viewed from an Arctic and insurance perspective. Ocean Coast. Manag. 2019, 179, 104853. [CrossRef]

26. Knol, M.; Arbo, P. Oil spill response in the Arctic: Norwegian experiences and future perspectives. Mar. Policy 2014, 50, 171-177. [CrossRef]

27. Bekareva, S.V.; Meltenisova, E.N.; Guerreiro, A. Oil Production Level as a Factor of Growing in the Arctic Economy (USA, Alaska). ECO 2019, 9, 155-164.

28. USGS. Circum-Arctic Resource Appraisal: Estimates of Undiscovered Oil and Gas North of the Arctic Circle. In USGS Fact Sheet 2008-3049. 2008. Available online: https:/ / pubs.usgs.gov/fs/2008/3049/ (accessed on 4 January 2022).

29. USGS. Summary Statistics of Results from the Circum-Arctic Resource Appraisal: Assessment Unit Codes Correspond to Labels on AUs Shown in Figures 1 and 2. 2008. Available online: http://www.arcticgaspipeline.com/Reference/Documents\& Presentations/Federal/USGS-Arctic_Gas_Potential_5-2009.pdf (accessed on 4 January 2022).

30. World Bank. World Development Indicators. 2020. Available online: https://databank.worldbank.org/source/worlddevelopment-indicators (accessed on 4 January 2022).

31. Zukerman, V.A. (Ed.) Innovation Factors in the Arctic Offshore Development and the Issues of Import Substitution: Joint Monograph; Publishing House of the Federal Research Center, Kola Scientific Center of the Russian Academy of Science: Apatity, Russia, 2019; p. 80 .

32. Malinauskaite, L.; Cook, D.; Davíðsdóttir, B.; Ögmundardóttir, H.; Roman, J. Ecosystem services in the Arctic: A thematic review. Ecosyst. Serv. 2019, 36, 100898. [CrossRef]

33. Devyatkin, P. Russia's Arctic Strategy: Energy Extraction. 2018. Available online: https://www.thearcticinstitute.org/russiasarctic-strategy-energy-extraction-part-three/ (accessed on 4 January 2022).

34. Chanysheva, A.; Ilinova, A. The Future of Russian Arctic Oil and Gas Projects: Problems of Assessing the Prospects. J. Mar. Sci. Eng. 2021, 9, 528. [CrossRef]

35. Glazkova, I.N.; Shabakaeva, S.D. Oil and Gas Production on the Arctic Shelf. Chronos 2019, 2, 70-72.

36. Lenchuk, E.B. Is Russia Ready for a Technological Breakthrough? Econ. Renaiss. Russ. 2020, 1, 43-49.

37. Grace Period. The State Encourages the Development of the Arctic Zone. Available online: https://www.gazprom-neft.ru/presscenter/sibneft-online/archive/2020-march/4373550/ (accessed on 4 January 2022). 
38. Dirani, F.; Ponomarenko, T. Contractual Systems in the Oil and Gas Sector: Current Status and Development. Energies 2021, 14, 5497. [CrossRef]

39. Central Dispatching Department of the Fuel and Energy Complex (CFU TEC). Available online: https://www.cdu.ru/ (accessed on 4 January 2022).

40. Dvorak, M. An Economic Assessment of Oil Development in the Alaskan Arctic. Master's Thesis, University of Washington, Seattle, WA, USA, 2017; 39p.

41. Kholmyanskii, M.A.; Pavlov, S.P.; Putikov, O.F. Application of the geoelectrochemical method for prospecting of oil and gas deposits in the Barents and Kara seas. J. Min. Inst. 2015, 215, 25-28.

42. Vasil'tsova, V.M. Problems development of the offshore oil and gas fields deposits. J. Min. Inst. 2016, 218, 345-350.

43. Zhdaneev, O.V.; Zaitsev, A.V.; Lobankov, V.M. Metrological support of equipment for geophysical research. J. Min. Inst. 2020, 246, 667-677. [CrossRef]

44. Galkin, S.V.; Krivoshchekov, S.N.; Kozyrev, N.D.; Kochnev, A.A.; Mengaliev, A.G. Accounting of geomechanical layer properties in multi-layer oil field development. J. Min. Inst. 2020, 244, 408-417. [CrossRef]

45. Litvinenko, V. Advancement of geomechanics and geodynamics at the mineral ore mining and underground space development. Geomechanics and Geodynamics of Rock Masses. In EUROCK2018: Geomechanics and Geodynamics of Rock Masses; CRC Press: Boca Raton, FL, USA, 2018; p. 14. Available online: https: / / www.scopus.com/record/display.uri?eid=2-s2.0-85061364238\&origin= resultslist (accessed on 4 January 2022).

46. Zyrin, V.O.; Ilinova, A.A. Problems of unconventional gas resources production in arctic zone. Russia Espac. 2018, 42, 17-24.

47. Bórawski, P.; Bełdycka-Bórawska, A.; Jankowski, K.J.; Dubis, B.; Dunn, J.W. Development of wind energy market in the European Union. Renew. Energy 2020, 161, 691-700. [CrossRef]

48. Cherepovitsyn, A.; Tsvetkova, A.; Komendantova, N. Approaches to Assessing the Strategic Sustainability of High-Risk Offshore Oil and Gas Projects. J. Mar. Sci. Eng. 2020, 8, 995. [CrossRef]

49. Nedosekin, A.O.; Rejshahrit, E.I.; Kozlovskij, A.N. Strategic approach to assessing economic sustainability objects of mineral resources sector of Russia. J. Min. Inst. 2019, 237, 354-360. [CrossRef]

50. Dmitrieva, D.M.; Romasheva, N.V. Sustainable Development of Oil and Gas Potential of the Arctic and Its Shelf Zone: The Role of Innovations. J. Mar. Sci. Eng. 2020, 8, 1003. [CrossRef]

51. Fetisov, V.G.; Pshenin, V.V.; Nagornov, D.O.; Lykov, Y.V.; Mohammadi, A.H. Evaluation of Pollutant Emissions into the Atmosphere during the Loading of Hydrocarbons in Marine Oil Tankers in the Arctic Region. J. Mar. Sci. Eng. $2020,8,917$. [CrossRef]

52. Raheem, N. Estimating annual costs to Inupiat subsistence hunting from a proposed infrastructure project in Alaska. Can. J. Nativ. Stud. 2014, 34, 125-145.

53. Archegov, V.B.; Nefedov, Y.V. Oil and gas exploration strategy in evaluation of fuel and energy potential of Russian arctic shelf. J. Min. Inst. 2015, 212, 6-12.

54. The Government of the Russian Federation. Available online: http:/ / government.ru/docs / (accessed on 4 January 2022).

55. Administration of the President of Russia. Available online: http://www.kremlin.ru/ (accessed on 4 January 2022). 